\title{
Supply Chain Shift from China: Is it Vietnam's Gain and India's Loss?
}

\author{
Cmde SL Deshmukh NM (Retd) ${ }^{1}$
}

\begin{abstract}
Supply chains are a life line for businesses. Without efficient, reliable and cost effective supply chains businesses cannot survive. China has been able to develop its industrial prowess well, to become a 'manufacturing hub' for the world and a major global supply chain partner. However, over the years problems started brewing for China for various reasons like rising wages, trade disputes etc. Many such factors probably came together which affected the supply chains in China.

Currently, Trade war and shift of supply chains out of China, mismanagement of Covid-19 Pandemic, South China Sea imbroglio seems to have hit China where it hurts. The 'Supply Chain Shift', apparently triggered by the 'USA-China Trade War' was expected to benefit many ASEAN countries particularly India and Vietnam. However, Vietnam has comparatively done better and has stolen the march over many countries and especially India-its nearest competitor.

Keeping in mind fairly serious impact on India's economy due to pandemic effects, lack of anticipated supply chain shifts, on account of Vietnam's gains, this article attempts to analyse concepts of supply chains, reasons for triggering shift of Supply Chains from China, prospects for countries in the region, Vietnam's edge over India in garnering benefits from that shift and India's strengths, weaknesses as well as impediments. The article suggests probable way forward to mitigate the same.
\end{abstract}

Keywords: Trade war, China, India, Vietnam, ASEAN, Supply Chain shift, USA, Manufacturing

\footnotetext{
${ }^{1}$ Commodore SL Deshmukh, NM (Retd) served in the Indian Navy for over three decades as a specialist in maintenance of fighter aircraft and ASW helicopters. He is currently the Senior Vice President of Sun Group's Aerospace \& Defence vertical. He is an independent researcher of strategic affairs.
} 


\section{Supply Chain Shift from China: Is it Vietnam's Gain and India's Loss?}

\section{Introduction}

The ever changing global economic situation has increased the inter country dependencies. With ongoing Globalisation many countries/companies look for cost effective solutions to boost their economic performance. It has, therefore, become essential to have supply chain networks cutting across the countries and organisations (Waller. n.d). This requirement has promoted effective integration of the global supply chains, creating a win-win situation for all the stake holders.

Increasing economic interdependencies have shattered the concept of traditional supply chains and supply chains have broken the so called borders barriers and become almost 'sans frontières'. In today's competitive world an Intense completion in the business world has necessitated efficient 'Supply Chain Management' which effectively integrates supply and demand dynamics, both within and across companies/borders/commodities (Ballou, 2006).

Supply Chains have now become more complex and integrated and have close linkages with geo-political equations between the countries. Thus it would not be surprising to see that a power struggle between US and China consequently cascaded into a "Trade war" between them (Wong and Koty, 2020). That in turn forced many companies (especially those linked with supplies to USA) to consider urgent shift of supply chains out of China, hitting China where it hurts. ASEAN countries, India, Bangladesh (with India and Vietnam as the Front Runners) were expected to benefit from this shift in Supply chains and had started gearing up for that. However, Vietnam seems to have stolen a march over all of them, especially over a comparable and strong contender like India.

This article (split in three parts) will examine concept of 'supply chains sans frontières', global geo-politico-economic developments leading to shifting of supply chains from China and associated issues; and, Compare India and Vietnam as alternate supply chain locations, their merits/demerits based on PESTLE and non-PESTLE analysis; specific impact on India and some measures to lessen the impact.

\section{Part-I}

\section{Section A: Analysis of Concept of Supply Chains and Events leading to shifting of Supply Chains from China}

\section{Concept-Supply Chains 'Sans Frontières'}

Concept of 'supply chain' refers to cohesion between a company or a business and its suppliers -to manufacture and distribute a specific product to the final buyer. Essentially the supply chain network includes different activities, people, entities, information, and resources. The 
supply chain also indicates process to get the product or service from its origin to the customer. Companies develop supply chains so they can reduce their costs and remain competitive in the business landscape (Kenton, 2020).

It has been observed that global supply chains related critical raw materials/ semi-finished goods are evolving as consumers and manufacturers are increasingly seeking reliable, sustainable and renewable options. Emerging digital technologies, including blockchain, Internet of Things (IoT) sensors and modelling tools have enabled these supply-chain transitions by their unprecedented capabilities for data visibility and analyses. At the same time, chemical manufacturers are turning toward process and chemistry innovations to improve the sustainability of their raw materials (Bailey, 2020)

With these tools at hand the procurement strategies are now focusing on different priorities to improve their alignment with business objectives. With a view to achieve cost optimisation, procurement strategies are adapting product and service innovations thus transforming from business process executers to business process enablers. This has made 'business services' truly borderless, from geographic, organizational, technology, and process standpoints. The tough completion has made standardization and globalization the mantras for enabling 'value add' by working across functions, business units, and geographic borders-supply chains 'sans frontières' ( Hackett Group, 2013).

Having examined 'supply chain' concept, let us now briefly examine aspects related to Supply Chain Management.

\section{Supply Chain Management (SCM)}

As supply chains have become more complex and crucial for businesses dependent economies, we need to clearly differentiate supply chain management from logistics management (Ballou, 2006a).

\section{Supply Chain Management}

Supply chain management (SCM) is an integrating function, having primary responsibility for linking major business functions and business processes within and across companies (which could be in different geographical locations) into a cohesive and high-performing business model. The SCM encompasses the planning and management of all activities involved in sourcing and procurement, conversion, and all Logistics Management activities. Thus Logistics Management forms a part of SCM that plans, implements, and controls the efficient forward and reverse flow of goods, services and information, between the point of origin and point of consumption in order to meet customer requirements (CSCMP Glossary ND), leading to the concept of 'supply chains sans frontières'.

\section{Geo-Politico-Economic Reasons for Supply Chain shift from China}

The recent sudden slide of China on various fronts has been monumental and did take many by a big surprise (Rapoza 2020). Somehow China seems to have gotten itself embroiled into 
too many disputes- including a trade war with USA-affecting it in various spheres, especially USA related supply chains in China, forcing them to shift to other locations.

However a peep into history would show that the signs of Chinese supply chains getting affected started emerging much earlier. For example, rising wages had started afflicting China since 2003; potentially eroding China's cost advantage in manufacture. It has been observed that between 1998 and 2003 China's unit labour costs were very competitive; however since 2003 they started rising in both absolute and relative terms. This phenomenon of exponential rise in China's relative unit labour costs was attributed to real appreciation of the yuan against the dollar, whereby costs almost matched those in the USA (Ceglowski and Golub, 2012).

But the real pressure for shifting of supply chains (out from China) started building up from the year 2008 for multiple reasons. The most important reason being changing geo-political situation coupled with rising competition. The uncertain global economic situation also affected the manufacturers in China, impacting their cost competitiveness. The above factors forced China towards an economic slowdown. The slowdown coupled with rising costs of business and tightening regulations just accelerated the board-level decisions, related to supply chain shift (Cyrill, 2019).

Viewed from a different angle, some other researchers observed that:

a) Rebalancing of global economy has been one of the factors. It has been pointed out that as several emerging economies (especially India, Bangladesh, and ASEAN) became the largest consumers and started demanding their pound of flesh. As a consequence, many multinational companies began relocating their supply chains in or around those markets. The expansion in trade and in services such as telecommunications, information technology, business services and finance created a fresh set of supply chains (Gupta, 2020)

b) Another big trigger for shift came in the form of ongoing China-United States trade war. USA's high tariffs and other trade barriers imposed on China as a punishment for its 'unfair trade practices' did trigger the shift. It has also been observed that since Jul 2018, the two countries got embroiled in countless back-and-forth negotiations, a tit-for-tat tariff wars, imposed foreign technology restrictions, fought several WTO cases, consequently leading to an almost a full blown trade war (Wong \& Koty, 2020a) .

c) A specific study on the subject USA-China Tariff War observed that many companies, including those related to key industries, had to seriously contemplate over shifting of supply chains (either partially or entirely) from China and look for most cost-effective supply chain strategy (Consultancy Asia, 2020)

d) China's problems were further exacerbated due to its worsening geo-political relations with many countries. As a result, many Governments started closely monitoring the import of Chinese-origin electronics and components, putting restrictions on the extent to which foreign firms could source higher-value technology items from China. 


\section{Pandemic Impact on Chinese Supply Chains- USA and Japan}

Covid-19 pandemic also had its own impact on supply chains in China. As quoted by Pamuk and Shalal (Pamuk and Shalal, 2020), Mr Keith Krach's (an undersecretary for economic growth, energy and environment in the US government) had said on the subject that:

The Trump Administration has been 'turbocharging' an initiative to remove global industrial supply chains from China as it examined various ways to 'punish' Beijing for its mishandling of the Covid-19 pandemic. These may include more tariffs and sanctions on China to push foreign companies to move outsourcing and manufacturing out of that country. A strong view has been emerging, shared by many countries that they should not depend upon an authoritarian, unaccountable and insecure China with its unfair and opaque processes, for procuring essential goods and services. US would thus consider setting up an 'Economic Prosperity Network' (EPN), a grouping of trusted partners like Japan, India, South Korea, Vietnam, Australia and New Zealand, which will work on the basis of similar standards on everything, from digital business, energy, infrastructure, research to trade, education and commerce.

To support above analysis following has also been observed (Singh, 2020):-

a) Two most important factors which forced many companies to rethink about their supply chains in China were effects of US-China Trade war and Covid-19 Pandemic.

b) In post pandemic era, trading partners may witness a completely different phenomenon is relation to supply chains. China - an important manufacturing hub for the majority of the businesses - may no longer remain a viable option for suppliers to US. Many U.S. companies have already started moving out of China, due to U.S - China trade war, corona pandemic and what USA terms as China's headstrong attitude.

\section{Decisions of Japanese Government on Chinese Supply Chains}

As in the case of USA, Japan also took a very firm stand about shifting of supply chains out from China. Researchers looking into this phenomenon observed the following:

a) Under the normal circumstances 'China-Japan' would have remained biggest trading partners, but in the pandemic era, imports from China slumped by almost half as the disease shuttered factories, in turn chocking supplies of essential components to the Japanese manufacturers. It prompted many Japanese firms to reduce their reliance on China as a manufacturing base. The Japanese government's panel on future investment also encouraged shifting high value added products manufacture back to Japan and diversification of production of other goods across Southeast Asia (Reynolds \& Urabe, 2020) 
b) Shinichi Seki (an economist at the Japan Research Institute) has been quoted as saying that "There will be something of a shift, as some Japanese companies, manufacturing goods in China for export, were already considering moving out. Having this in the budget will definitely provide an impetus", (Reynolds and Urabe, 2020a). As we know, Japan has earmarked $\$ 2.2$ billion of its record economic stimulus package, to help its manufacturers shift production out of China (ETAuto2020).

It is evident that China's abrasive attitude toward South East Asian nations, unreasonable territorial/EEZ claims and threats to oils platforms in South China Sea, denying 'freedom of navigation' especially to the US Ships, did trigger negative fallouts for China. Emerging discomfort of South East Asian nations/Australia/Japan, USA resulted in cascading reactions like ASEAN/BIMSTEC nations coming together for formulating a credible response to China's arrogance and emergence of QUAD (India/Australia/Japan/USA) to thwart unfair ambitions of China. If these signs were viewed in conjunction with the analysis above, reasons for imperative need for shifting of supply chains from China would be quite evident.

\section{Section B: Counter view regarding Shift of supply chains out of China \& Reality}

Every coin has two sides. Some other researchers (analysing the supply chain shift from China) have opined that though the necessity for shift of supply chains out of China might have been strongly felt, it would not be an easy task.

Analysis has revealed that the task of establishing alternate supply chains has been easier said than done for the:-

a) Supply chain industry which was exploring various ways to move components out of high-risk Chinese market.

b) Organisations looking for reorganising their supply chain mix, to cope better with the 'new normal' emerging post Covid-19. (Consultancy Asia 2020a)

c) Companies exploring feasibility of using Asian facilities as an alternate to China Supply chains. Even though the companies found that India, Vietnam, Indonesia and other ASEAN countries had prepared well to receive supply chains, in reality they were not ready to qualify as competitors to China. Thus, moving the supply chains from China has not been that easy for these companies. In fact, it seems unlikely that companies can easily abandon operating in China altogether. The best they could do is shift bits and pieces to other locations (Consultancy Asia 2020b).

Foxconn's example can well illustrate the ripples above mentioned crisis caused for supply chains. Foxconn - a contract-based electronic manufacturer with production plants in Chinasuffered serious disruptions to its supply chain, when the crisis began, which in turn impacted the supply chain of its buyers, which included tech giants like Apple, Intel and Sony. This topped off an already uncertain climate, as tensions between China and USA escalated in 2019. 
Due to the above, the decision of shifting supply chains out of China, which prima-facie seemed simple enough, in reality threw up challenges even relocating to Asia/ASEAN. Despite targeted efforts from markets in the region, it became evident that the shift might take a few years, before the Asia/ASEAN region could catch-up with China. It was observed that three competitive advantages that continued to give China supply chain supremacy (Consultancy Asia 2020c) were:-
a) Availability of Skilled labour
b) Access to an extensive network of suppliers
c) Highly developed logistics infrastructure

The Consultancy Asia (ibid) report brought out that:

All the above factors have come together and delayed or minimised the supply chain restructuring drive away from China. It has become clear that many challenges still loom for companies that have been planning to move to Southeast Asia from China. Consequently, most companies have relocated only some - and not all - of their operations in China into Southeast Asia.

As far Japan is concerned, Reynolds and Urabe (Reynolds and Urabe 2020b) have reported that despite decision to shift, it may not be easy and Companies manufacturing cars for the Chinese domestic market would most likely stay put.

\section{Factual Status}

Despite above counterview, many companies have been seriously thinking of shifting their supply chains out of China. Researchers like Consultancy Asia observed that out of 250 respondents surveyed by the American Chamber in China: $25 \%$ were heading to Southeast Asia, while $11 \%$ were going to Mexico, $8 \%$ to Indian subcontinent, $6 \%$ to the US, $4 \%$ to East Asia and $4 \%$ to Europe.

It was also observed that Beijing did mishandle the pandemic and tried to bully the world. Consequently, corporate leaders started losing confidence in China, resulting in many foreign companies willing to move out, both- sourcing and manufacturing out of China and China certainly has none to blame (Consultancy Asia 2020d)

Some other statistical facts presented by Khan (Khan, 2020) also support the above observations:-

a) $33 \%$ of companies with global supply chains have already moved their manufacturing activities out of China or planning to do so in the coming 2-3 years. 
b) More than 50 multinationals from Apple to Nintendo to Dell have been rushing to escape the punitive tariffs placed by the U.S, thereby accelerating the pace of companies moving production out of China.

Fig 1: US Firms Shifting Out From China

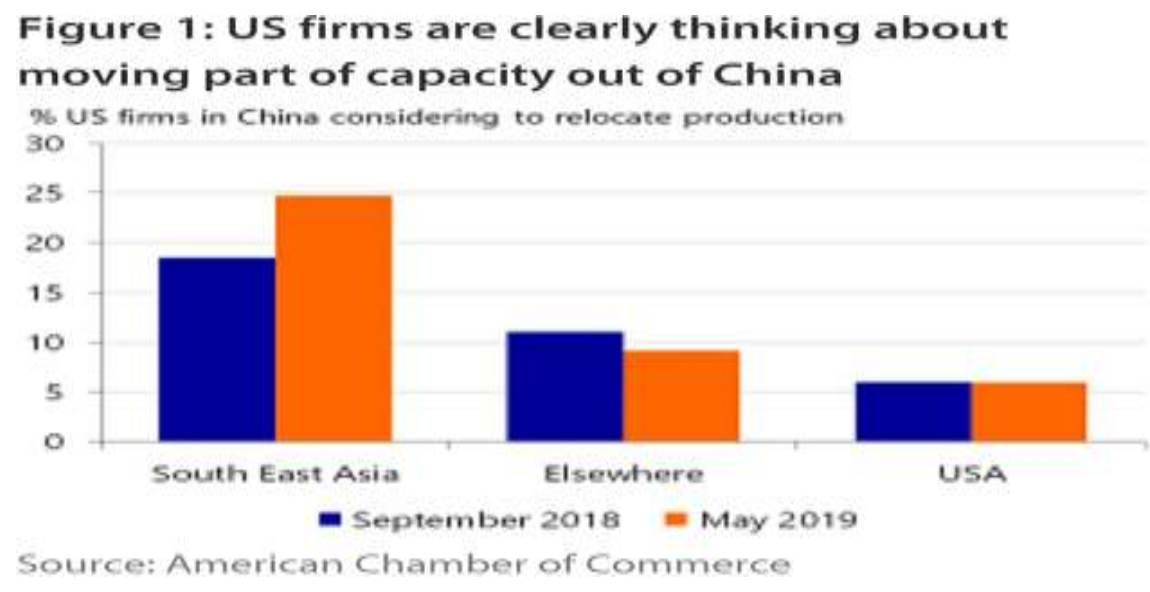

American Chamber of Commerce did appreciate this phenomena and has been constantly helping US Firms to shift their supply chains from China to various global locations like South East Asia, USA or elsewhere (Fig:1 refers).

In case of Japan, Reynolds and Urabe (Reynolds \& Urabe, 2020c) have stated that a survey by Tokyo Shoko Research Ltd. found 37\% of the more than 2,600 companies that responded were diversifying procurement to places other than China amid the coronavirus crisis.

The above findings have also been backed by surveys undertaken by Garner Incorporated and published by DC Velocity (DC Velocity, 2020). The survey brought out that one third of companies with global supply chains have moved their sourcing and manufacturing activities out of China or plan to do so in the next two to three years.

Survey also brought that though Covid-19 pandemic was certainly one of the top reasons for the trend, other powerful factors were U.K.'s economic withdrawal from the European Union (Brexit), and high tariffs imposed by President Trump's trade war with China. Gartner's "Weathering the Supply Chain Storm" survey gathered data from 260 global respondents between February and March 2020. Participants were responsible for supply chain and related functions across a range of industries, including high-tech, industrial, and food \& beverages (DC Velocity, ibid).

As seen from the above there are multiple views about shifting of Supply Chains from China, ranging from quick shift, guarded shift, not easy to shift etc. However, a fact remains- US's 
tough stand has forced companies to do a serious rethink about shifting and it has become at least a partial reality, certainly impacting China.

\section{Section C: Comparative analysis of countries vying to benefit from shift of supply chains from China}

As shifting of supply chains (from China) to other competitive locations became an imperative, despite numerous difficulties faced by the global companies, it was accepted by many business chambers and trade associations, as a fait-accompli. In turn, they came up with comprehensive analysis of various countries, to help the companies in making informed decisions.

Historically, the U.S. producers began manufacturing operations in China sometime in 1990s for only one reason: costs. But the trade war brought a second important factor into the equation: risk. Higher tariffs and the threat of disrupted Chinese imports forced many companies to weigh surety of supply more fully along with the related costs. As if this was not enough, COVID-19 brought the third factor more fully into the picture: resilience-the ability to foresee and adapt to unexpected shocks (Singh, 2020a).

Many Senior Executives of multinational corporates acknowledged the global pandemic situation as dynamic and disruptive but expressed some confidence about their ability to weather the storm with a diversified supply chain.

Various country-wise studies on the subject and especially that of Singh (ibid) brought out some important aspects.

\section{Vietnam}

It has been observed that despite all the uncertainties, a country (though an underdog) found capable of offering almost all the possible benefits provided by its counterpart China- was Vietnam. Vietnam- a southeast nation which has enjoyed high success in creating an adaptable production base - has geared itself towards higher valued manufacturing operations. It has been pointed out that as per study conducted by Natixis SA to evaluate seven emerging Asian economies, as manufacturing alternatives to China, Vietnam was ranked number One. Several factors such as demographics, low wages, the World Bank's Doing Business rankings, and logistics were considered to determine the manufacturing options (Mah, 2019).

\section{Mexico}

Geopolitics expert Peter Zeihan, author of Disunited Nations, believed that Mexico is wellpositioned to capture new business. "As Mexican manufacturing capacity is both less expensive and more efficient than most manufacturing in China and Canada, Mexico will certainly pick up a disproportionate share of whatever relocates to the North American market," he said (Blackham2020). A general breakdown of the global order due to pandemic and Mexico's now even more-privileged access to the American market has made Mexico's chances brighter. 
Mexico offers several distinct advantages over China as a manufacturing partner, for companies around. Such as:

- Ground transport. Ease of import of Goods from Mexico via ground transport in a matter of days or even hours. This can never be an option for goods manufactured in China, as everything would warrant passage by sea or air. The former is very time consuming (it can often take weeks), and the latter quite expensive.

- Trusted partner" status for customs. The U.S. offers two programs that help facilitate faster and easier Customs processing for U.S.-Mexico trade: FAST and C-TPAT. Initiated after 9/11, FAST is a trusted traveller/trusted shipper program that allows expedited processing for commercial carriers who have completed background checks and fulfil certain eligibility requirements (much like TSA Pre-check for air travellers). FAST certification is for drivers; C-TPAT is a broader program that shippers must apply for. Once a company is certified for C-TPAT, its drivers can then apply for FAST. There are no such programs for U.S.-China trade or any other nation.

- Stronger IP law and protections. It is relatively common for manufacturers in China to replicate U.S. product designs. Intellectual property laws in Mexico are much stronger, making it far less likely that products will be replicated. And if they are, there is legal recourse.

- Smaller language barrier. Spanish is the second-most common language spoken in the U.S., making it relatively easy to communicate with partners in Mexico (and find bilingual staff and vendors).

- Time-zone parity: Mexico operates on the same time zones found in the U.S. Eastern, Central, Mountain and Pacific.

It has been reported that of out of 160 U.S.-based industries almost two-thirds have moved, plan to move, or are considering moving some of their operations to Mexico, citing global trade tensions as the primary reason for such an initiative (Blackman 2020a).

\section{Exploring other Options}

The Business world has been considering Taiwan, India, and Brazil as viable alternatives, but in reality none of these countries could provide a more complete solution than that provided by either Vietnam or Mexico. For instance, India has the infrastructure and a well-balanced manufacturing ecosystem but the country's logistics industry has proven to be a complete nightmare. Though Brazil does seem to be good for consumer packaged goods (CPG) companies, but operating in Brazil has its own challenges. Even at the best of times, Brazil has a tough environment to manage a supply chain for a variety of reasons geographic, structural, and practical. Besides, Brazil's complex and volatile tax policy, a major factor taken into 
consideration by the supply chain businesses, puts it in a more difficult situation Taiwan posed challenges due to its close geographical proximity to China (Singh, 2020b and Roy 2020).

\section{Reasons for cautionary move by Manufacturers}

Though many countries have been vying for grabbing the Supply chain shift business, but the companies shifting their supply chains have been cautious in doing so. Singh (Singh, 2020c) has rightly brought out that "while many big tech. companies such as Apple, Google, and Microsoft have started looking for alternatives, it may not be an easy ride".

Another factor which has been bothering the companies contemplating the shift, relates to probable dependence of new non China supply chain partners and tier-one suppliers on China, for their raw materials. For example, Vietnam imports up to $60 \%$ of its raw materials in the garment industry from China. Further, the relocation has its own (generally high) costs. They include costs of converting and transferring industrial plants into appropriate regions, transferring production lines and sending qualified workers into a new country. This may not be a big challenge for large multinationals but for smaller businesses; this could be a risky alternative (Singh ibid/Coates, 2021).

Thus in summary, though the companies looking for shift of supply chains out of China have had multiple choices in terms of countries, it has not be a cake walk for them, The main reasons being dependence on China for raw materials, non-availability of skilled manpower, inefficient manufacturing capabilities and inadequate logistical networks in those areas. These impediments have had an impact on the pace of shift of supply chains. In comparison with ASEAN countries Mexico, Vietnam and India may seem to be faring better, but they would succeed only if they match China in terms of efficiency and quality. Despite it being a tall order, it would be imperative for India to embark on that journey, if it wants to survive the competition.

\section{Part-II}

\section{Section D: Comparison of Vietnam and India}

Interestingly, "Both India and Vietnam perceive China as an irredentist and expansionist power that can never be territorially satiated and therefore presents a clear and present danger. India seeks to do to China what China has done to India, that is, containment and encirclement," Mohan Malik, a visiting fellow of the NESA Centre for Strategic Studies [a regional centre of the US Department of Defence]. Malik has also stated that New Delhi has now taken a firm stand against growing Chinese expansion in India (Xavier, 2020).

Despite the fact that Vietnam and India have many common interests, they compete with each in the business environment. On most trade indicators, Vietnam scores over India and it's not shy of going all out to woo firms moving out of China. 
In support of the above view, Muzumdar (Muzumdar, 2020) has brought out that "As India continues to atone over its inability to keep pace with China; it is increasingly missing the bus with Vietnam as well. While Vietnam started the Doi Moi reform process in 1986, after China in late 1970s, and before India in 1991, there is little doubt that Vietnam has achieved massive economic success". Today USA receives more garments from China, Bangladesh and Vietnam than from India.

He opined that with Covid-19 crisis "China has been facing a unique global withdrawal threatening to destabilise its sway as the world's factory of choice". Amidst this, Vietnam has emerged as the preferred choice of electronics and mobile phone companies, trying to move out of China.

Other analysts have pointed out that Vietnam's emergence as an alternative manufacturing hub to China had started even before beginning of historic trade war between Washington and Beijing, and thus gained advantage as the need for supply chain shift from China assumed urgency.

Vietnam has been largely benefited by the ever-changing policies as per the market demand. Former Prime Minister of Vietnam Nguyen Tan Dung had even written for the World Economic Forum that "It was the vigorous changes in the business and investment climate that made the country attractive for FDI".

Further, Vietnam's socio-political stability and population structure helped it win investors' trust. It is important to note that Vietnam had initially allowed the state-owned enterprise to compete with foreign investors, but witnessing attacks on foreign-owned enterprises, the government immediately switched the policy.

The recent free trade agreement between Vietnam and the European Union has also benefitted the country, as the EU lifted 85 percent of its tariffs on Vietnamese goods in 2020 (Sharma 2021/Eurasian Times2021).

\section{Leaping forward}

It has also been observed that Vietnam's total merchandise exports grew at an annualised average rate of 18 per cent in the last 10 years till 2019 (Fig: 2), as compared with India's 5 per cent. During the same period, Vietnam attained a trade surplus of $\$ 47$ billion, which again was a significant improvement over the trade deficit of $\$ 13$ billion in 2010. While Vietnam started delivering trade surplus, India's trade deficit increased to $\$ 156$ billion in 2019 from $\$ 130$ billion in 2010 (Muzumdar, 2020a).

Fig: 2 Vietnam Exports 


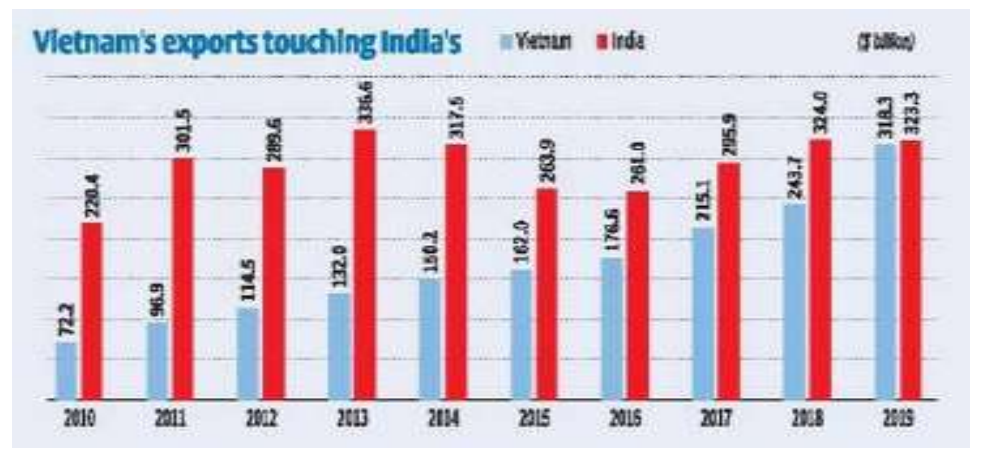

Image courtesy: The Hindu

Vietnam's top exports, in 2019, comprised electrical machinery and equipment (with 41 per cent share), apparel (11 per cent), footwear (8), and machinery and mechanical appliances (5). The highest increase in exports during 2010-19 was in electrical machinery and equipment Mobile telephones (13\%) and Integrated Electronic Circuits (7\%) recorded the highest increase. The US, the UAE and Austria accounted for 40 per cent of the mobile phone exports by Vietnam in 2019.

In comparison to Vietnam's manufacturing and technology-oriented exports, India's top exports comprised largely low-tech manufacturing products like mineral fuels (14 per cent share), pearls (11 per cent), machinery (6), organic chemicals (5) and vehicles (5). India could have been an ideal destination for hi-tech manufacturing, but Vietnam has been the frontrunner. Hi-tech exports as a percentage of manufacturing in Vietnam stands at 40 per cent, whereas in the case of India it stands abysmally low, at 9 per cent in 2018.

For cite an example, in 2012 Samsung (South Korea) established a dedicated LFD business, Samsung Display Solutions, catering to the company's SMART range of LED products. In fact, the company assembles half of its global handsets in Vietnam and has benefited hugely post the US-China trade war.

The total sales by Samsung Electronics in Vietnam amounted to $\$ 66$ billion which accounted for as much as 28 per cent of the country's GDP. Reportedly, in such cases, Samsung has provisionally decided to diversify its production lines for making smartphones to India under the PLI (Production Linked Incentive) scheme- should this happen it will be a boon for India.

One more factor which stands in favour of Vietnam has been ratification of its FTA with the EU in Jun 2018, which essentially allowed European producers to invest in Vietnam and export further, from there, into other markets in Asia-Pacific, to which Vietnam provided a preferential access. India has been found wanting in this sphere.

Unfortunately, this has occurred when Indian exporters have been losing market share to Vietnam in the EU market. India's share to EU accounts for close to one-fifth of Indian outbound shipments. During 2009 and 2018, India's exports to EU increased 1.6 times as against Vietnam's 4.4 times (Muzumdar, 2020b and Mah, 2019a)

Given the ongoing worldwide trends, if production continues to shift out of China, post trade war, it would make sense for businesses to go into Vietnam. Once firms establish themselves 
in Vietnam, they can consider re-exporting back to China, or enlarge their operations to other ASEAN economies and the EU. Sadly, India would remain bereft of these benefits owing to its bureaucratic processes.

Other analysts also have expressed similar opinions. It has been observed that even tough India offers global investors a large and attractive market, a sizeable demographic advantage and a vibrant private sector, there are some major lacunae that need to be addressed if India wants to harness its potential for becoming a global manufacturing hub. Two of the most important impediments are poor infrastructure and stifling bureaucracy.

There is no doubt that infrastructure development is an important key to lifting India out of its worst economic crisis since independence. Realising this Indian Government has paid a great deal of attention to the Infrastructure spending has, therefore, received a great deal of attention from the government, but a lot needs to be done.

Complex government regulations, bureaucratic red tape and considerable variance in central and state government jurisdictions have been cited by global manufacturers as big hurdles in India. (Bansal 2020)

It is seen from the above India has so far failed to encash on its inherent capabilities and fallen behind Vietnam in a big way. India needs to realise this folly and start putting remedial measures in place on a war footing.

\section{Section E: Vietnam's appeal- Preference by multinational manufacturing firms}

A factual analysis also has clearly shown that in comparison to India, Vietnam has fared better in garnering major benefits from the Supply Chain Shifts ex-China.

Mah (Mah, 2019b), based on a study conducted by Natixis SA (which evaluated seven emerging Asian economies as manufacturing alternatives to China) has observed that Vietnam was ranked number one. The study examined demographics, low wages, the World Bank's Doing Business rankings, and logistics to determine manufacturing options.

She brought out that "The Vietnamese government has strategically transformed the nation into a 'China plus one' alternative, by engaging in numerous free trade deals such as the Comprehensive and Progressive Agreement for Trans-Pacific Partnership (CPTPP) and EU Vietnam FTA (EVFTA), while developing its infrastructure to become a source for global export'.

Vietnam has received some of China's labour-intensive manufacturing, and this trend is most likely to continue given the government's willingness to make progressive economic changes. Over the course of the last few decades, the implementation of market features, such as openness and trade, have become pillars for its economic restructuring. For example, Vietnam joined the World Trade Organization (WTO) in 2007 in a significant step towards merging with the global economy. Since then, several international trade arrangements to create favourable tax and investment terms have followed. 
To corroborate above view, Kumar (Kumar, 2020) has said;

With regard to Vietnam, the country's geographic location, facilitating connectivity with other countries, makes it a suitable hub for manufacturing. Forty-four key seaports dot its 3,260-km coastline, managing 400-500 million tons of cargo annually; however, this is significantly lower than India. Additionally, the cost of shipping from Vietnam to the US, South Korea and Japan is higher (by 50-100\%) compared to India. These factors make Vietnam a less favourable destination. But Vietnam compensates for these by offering a better business environment.

Other researchers have also supported the view that Vietnam has evolved as an attractive destination for FDI, as it is increasingly providing cheap labour whilst offering a friendly environment and reduction in taxes to foreign enterprises. According to data available, out of 56 companies that have moved out of China since its trade war with US, only eight have invested in India, while 26 shifted bases to Vietnam (Muzumdar, 2020c).

\section{Specific Product Supply chains shift to Vietnam}

It would be easy to reckon that the textile and garment sector have been two of Vietnam's major areas of export, in that Vietnam stands as the second largest textile and garment supplier to South Korea after China. Industry observers also anticipate that Vietnam will soon take the top spot." The Vietnamese Governmental support has been crucial in this achievement (Mah, 2019c) .

In recent years, multinational retail giants, such as Nike and Adidas, have also broadened their manufacturing bases to Vietnam because of cheaper labour costs. Nike began to manufacture more of its product line in Vietnam than China starting in 2009, and Adidas soon followed in 2012. Vietnam's high-tech boom in recent years has paved the way for the country to begin producing more higher-end goods. This is seen in the recent trend of electronics goods factories making the shift to Vietnam.

\section{Future supply chain shifts to Vietnam}

As technology evolves, automation is most likely to replace low-cost factory production. This will create a greater demand for workers in the field of component manufacturing and assembly of electronics - like electronic components on printed circuit boards. In summary Mah (ibid) said that "Vietnam's proximity to China, its growing skilled workforce, competitive labour costs, and political stability make it an ideal manufacturing destination. Especially as component manufacturing is a complex process - one that needs to allow room for trial and error".

It is evident from the above that though India has many pluses on its side, Vietnam has still proven itself to be a preferred destination for supply chain shift, albeit at the cost of India. 
In addition to the factors described above, some other factors also could have hampered India's prospects. Author would like to make a reference to a report (Dutta, 2020) which states that the shift sentiment did raise hopes in India that it would be able to attract much of the businesses, due to its democratic polity and open market. However, the reality turned out to be different.

Qima (a reputed Hong Kong based company) poll of over 200 businesses with global supply chains, 87 per cent of respondents said coronavirus pandemic had triggered significant changes in the global supply chain. More than 50 per cent noted that they had begun switching to suppliers in unaffected regions (Dutta ibid).

Qima report also underscored the fact that the companies were looking for "safer" destinations which in post-Covid times inter alia referring to the countries that managed coronavirus pandemic better. Vietnam, incidentally, did emerge as a model country in the fight against coronavirus pandemic, perceived probably as better in comparison to India.

This explains why India may not have been the preferred destination for companies which were actually shifting or have plans to relocate out of China. India's large market access has not been the only determining factor for them, even when the country has been considered the closest rival to China.

Further, referring to a study by Japanese financial group Nomura, Dutta (ibid) has pointed out that out of the 56 companies shifting their supply chains to South East Asia, Vietnam got 26 of them. Taiwan got 11 and Thailand eight. Only three companies came to India.

Another study on the abject has brought out some of the factors that make Vietnam better than its peers are (Eurasian Times, 2021a):-

a) Incentives for international firms for setting up units to manufacture hi-tech products,

b) Pool of low-cost workers

c) Proliferation of free trade agreements.

The said report also brought out that Vietnam has fared better than both India and China in the FDI policy. India remains behind both China and Vietnam in foreign trade and exchange controls.

Undoubtedly India needs to do a thorough analysis of various factors to formulate its response strategy for attracting supply chains to India. 


\section{Part-III}

\section{Section F: India's Strengths and Weaknesses}

\section{Strengths- Reasons in Favour of India}

China for more than two decades has been functioning as a global production hub for companies in multiple industries, such as electronics, textile, medical devices, and automotive. However, the scenario changed in 2019, when many multinationals decided to shift manufacturing (partially or fully) to other low-cost destinations, especially to India and Vietnam (Kumar, 2020a), for the reasons explained above. A comparative market evaluation (Fig: 3 ) shows emergence of India and Vietnam as viable alternatives to China.

\section{Fig:3 -Emerging Asia Market Evaluation}

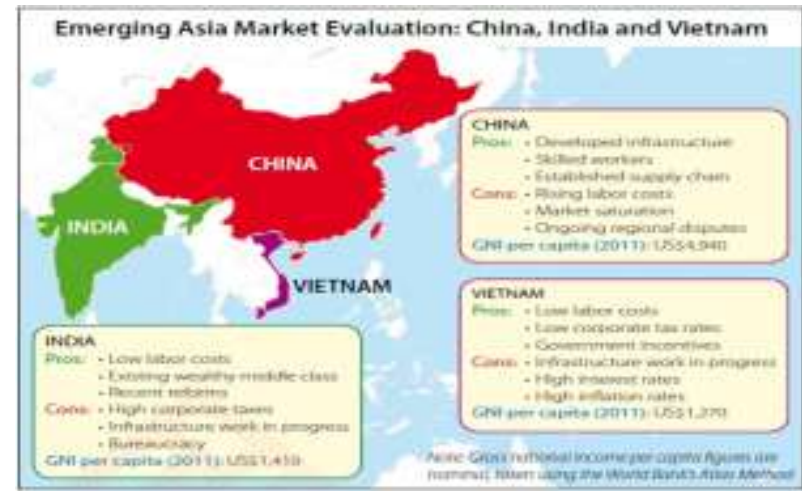

Image Courtesy: Dezan Shira and Associates

\section{Indian Government's Initiatives}

Central and state governments in India have been working actively to attract global manufacturing companies shifting base from China. For example, Uttar Pradesh, Tamil Nadu and Karnataka have offered incentives, setting up a special investment promotion task force and implementing fast-track clearance programs to lure US companies. The Government of India has developed a land pool of 461,589 hectares, nearly twice as big as Luxembourg, to attract businesses looking for replacements to China. In 2019, India was one of the top 10 recipients of FDI, totalling US\$ 49 billion, up 16\% from that the previous year. The Indian government recently allowed up to $100 \%$ FDI in contract manufacturing, aiming to increase the share of investments in manufacturing in total FDI (Kumar, 2020b).

\section{Availability of Port Infrastructure:}

According to the World Economic Forum, India ranked 51st among countries on the Quality of Ports Infrastructure Index. Vietnam holds the 85th position. The Indian government has spent US $\$ 1.85$ billion on infrastructure development at major ports in the country. It has permitted up to $100 \%$ FDI on projects related to ports and offers a 10-year tax holiday pertaining to the construction and maintenance of ports and harbours. As per world rankings 
India stands at $51^{\text {st }}$ and Vietnam at $85^{\text {th }}$ Rank (Global economy Rankings, 2019). A big plus for India,

\section{Technology adoption and automation}

India ranked 18th and Vietnam 24th on the Automation Readiness Index. Additionally, India's gross expenditure on R\&D, as a percentage of GDP, has been almost double compared with Vietnam's. The Indian government has been seriously working on preparing a blueprint to speed up digital manufacturing transformation (The Economist Report, 2018).

Other factors which stand in favour of India include:-

a) Lowest tax rates among Southeast Asian countries

b) Low labour cost and ease of availability

c) Large Domestic Consumption

d) Availability of Raw Materials

It would be seen that though India prepared itself reasonably well to reap the benefits of supply chain shift from China, but that hasn't been good enough. Vietnam has certainly fared better than India in that aspect.

\section{Weaknesses- Reasons against India}

It is opined that to really benefit from supply chain shift from China, India would need to address quite a few issues seen as challenges by the companies looking for shift, such as difficulty in doing business, long-drawn land acquisition process, low productivity due to outdated technologies, poor manufacturing quality, inadequate cargo handling capabilities, lacking "ports and roads" connectivity, bureaucratic processes, lack of transparent approval mechanisms, to cite a few too many. India certainly needs to overcome these challenges quickly, to emerge as a chosen destination for the supply chains and manufacturing hubs and prove it to be a better place for doing business.

\section{Comparative Analysis of Economic Performance -Vietnam and India}

Before proceeding further a quick comparison between economic performance of Vietnam and India could help in understanding India's situation better. A Comparative study (Vu \& Asher, 2009), has found that despite differences in size, geography, economic structure, and past policies, both countries offer contrasting yet revealing insights at the possibilities concerning their respective policy priorities, during their economic reform period (1990 to 2008).

The study observed that while the two countries achieved high economic growth over the 19902008 period, their growth patterns differed in three aspects:-

a) Economic growth accelerated for India between the first 6-year sub-period 1990-1996 and the last sub-period 2002-2008, while this trend was reversed for Vietnam; 
b) The service sector was the major driver of India's growth performance, while the industrial sector played this role for Vietnam;

c) Vietnam relied heavily on capital investment, while India relied on "Total Factor Productivity" (TFP) growth for sustaining high growth in GDP and in labour productivity.

The study observed that India had focused on improving business environment, Upgrading infrastructure and more result-oriented social expenditure, particularly in education. Vietnam in turn focused on improving the quality of governance; being more efficient and prudent in making investments and more selective in attracting FDI and promoting the growth of the services sector.

It was also brought out that India and Vietnam could learn from each other. For example, India could share its vast experience in attracting knowledge intensive FDI involving service transactions in the Information and Communication technology, financial services, and in research and development with Vietnam, while Vietnam can share its experience in attracting labour-intensive investments (Vu \&Asher, ibid).

It is opined that India certainly has competence and resilience to set the required reforms in motions and be relevant in competition with Vietnam. It also important that India may consider partnering with Vietnam, in a manner which could not only c create a win-win situation for both the countries, but also create a string allay for India.

\section{Section G- India Vs Vietnam- PESTLE Analysis}

\section{PESTLE Analysis (PA) - An Important Business Analysis Tool}

Before focussing on the implications for India, it would be relevant to briefly understand concepts of the "PESTLE Analysis (PA)". (pestleanalysis.com). PESTLE Analysis, have explained the analysis concept stating that:

The 'PESTLE Analysis' which is sometimes referred to as PEST analysis, is a concept in marketing principles. Moreover, this concept is used as a tool by companies to track the environment they're operating in or are planning to launch a new project/product/service, etc.

PESTLE is a mnemonic which in its expanded form denotes $\mathrm{P}$ for Political, E for Economic, $\mathrm{S}$ for Social, T for Technological, L for Legal and E for Environmental. It gives a bird's eye view of the whole environment from many different angles that one wants to check and keep a track of while contemplating a certain idea/plan. All the aspects of this technique are crucial for any industry a business might be in. More than just understanding the market, this framework represents one of the vertebras of the backbone of strategic management that not 
only defines what a company should do but also accounts for an organization's goals and the strategies stringed to them.

PESTLE Analysists recommend that relevant data related to the above factors needs to be analysed based on the business category. It may happen that importance of each of the factors may be different for different kinds of industries, but it is imperative to any strategy a company wants to develop. It needs to be noted that the PESTLE analysis is a much more Comprehensive tool as compared to the standard 'SWOT' (Strengths/ Weaknesses/ Opportunities / Threats) analysis.

Professional Academy has explained concepts (Professional Academy Blog, ND) of the 'PESTEL Analysis' simplistically as: "PESTEL analysis or more recently named PESTLE is a framework or tool used by marketers to analyse and monitor the macro-environmental (external marketing environment- Fig: 4) factors that have an impact on an organisation". The results of such analysis are more accurate than the standard SWOT analysis.

Fig: 4- PESTLE Analysis

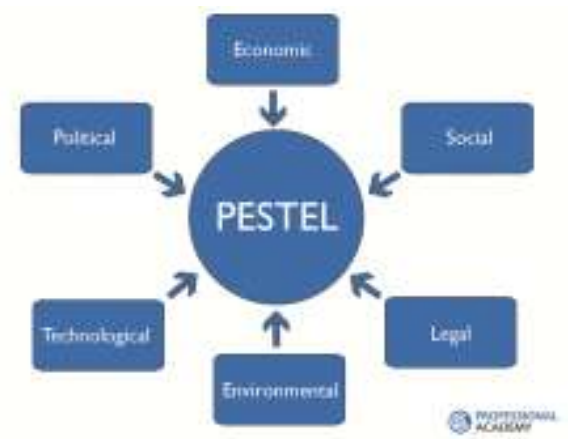

All the external environmental factors (PESTEL factor

Image Courtesy: Professional Academy

\section{Comparative PESTLE Analysis India Vs Vietnam}

It has been observed that many Companies prefer to conduct PESTLE Analysis primarily to check best country / place for starting business / shifting their business (Professional Academy Blog ibid). Detailed comparative studies have been undertaken in relation to Indian and Vietnam. Companies exiting china have found Vietnam better when compared with India in most of the PESTLE factors. Let us analyse the same for India and Vietnam. Base year of 2029 has been used.

\section{Political Factors}

Global Economic Survey (Globaleconomic.com, nd) uses scale of -2.5 weak to +2.5 strong to calculate Political stability index. Based on the data for India from 1996 to 2019, the average value for India during that period was -1.11 points with a minimum of -1.51 points in 2003 and a maximum of -0.7 points in 2019 . 
For Vietnam the average value for Vietnam during that period was 0.24 points with a minimum of -0.02 points in 2014 and a maximum of 0.53 points in 1996.

On the other hand WIPO has ranked India 71st and Vietnam 57th (WIPO-Cornell University, 2019). It is thus seen Vietnam scored better that India in Political stability. Regrettably even today the things have not changed much.

\section{Economic Factors}

Indian Economy continued to falter in 2019. The Budget came up with policy changes that seemed to deal with symptoms and not causes. The budget was found to be reactive rather than proactive and measures were not enough to stem the economic slide (India Today, 2019).

The Reserve Bank of India Report (2019) also confirmed the fact that though India's financial system remained stables the economic growth plummeted to a six-year low. "Reviving the twin engines of consumption and investment while being vigilant about spill overs from global financial markets remains a critical challenge going forward," the RBI Report (FSR19, 2019) stated.

In comparison, Vietnam's economy had performed well in 2019. The GDP improved with an estimated 6.8 percent, public debt reduced by almost 8 percentage point of GDP since 2016 . Vietnam's emerging middle class, currently accounting for 13 percent of the population, is expected to reach 26 percent by 2026- a growing market indicator. Vietnam also achieved trade balance surplus for the fourth year in a row. These results are certainly remarkable in the context of a slowing global economy (World Bank Report, 2019). Here too Vietnam Scored over India.

\section{Social Factors}

India- with its 1.2 billion population - is reeling under resource crunch. The country is faced with many issues related to quality of education, rising unemployment, poverty, caste system ills. Social and economic differences along communal and caste lines have resulted in a lopsided growth in India which favours the higher castes and fails to unlock the tremendous potential of labouring classes.

India currently boasts of demographic dividend. But it largely depends on the value add from the current and future generations. It is lost if a country's young population is not educated, healthy and properly skilled or largely remains unemployed (Shariff, 2020).

Vietnam experienced rapid demographic and social change during 1986-2019. Its population reached a figure 96.2 million in 2019, up from about 60 million in 1986. According to the 2019 Population Census Report, 55.5 percent of the population is under 35 years of age, with a life expectancy of 76 years, highest among countries in the region at similar income levels. (World Bank, 2019a).

Vietnamese achieved better social and -economic development in 2019, despite sluggish growth of the world economy along with increasing risks and challenges like trade wars, BREXIT, China's hegemony etc. The increasing trend of protectionism and geopolitical changes which were challenges for the world economy did affect the Vietnamese economy too. 
Despite this the Vietnam's social economy continued to have positive changes, of which macroeconomics was stable, inflation was controlled at a low level. The Vietnam Government's continued focus on solutions to cope with difficulties in production and business and social sectors, ensured growth targets for 2019 were achieved (Comconnect2019 and GSO Vietnam, 2019)

Vietnam is ahead of India in initiatives related to education. It started compulsory education 8 years ahead of India and spends more amount than India when compared as a percentage of respective country's GDP (WB Report, 2020).

Geographical location of the country is also analysed under Social Factors. Location wise Vietnam is the country nearest to the China's Manufacturing Hub - Shenzhen (Fig 5 refers). We have seen that the Countries moving from china may not move $100 \%$ of their capacity from China (based on cost \& time factors). Locational wise movement of raw materials from Shenzhen will be cheaper for Vietnam.

Fig: 5- China Vietnam- Georgraphic Location

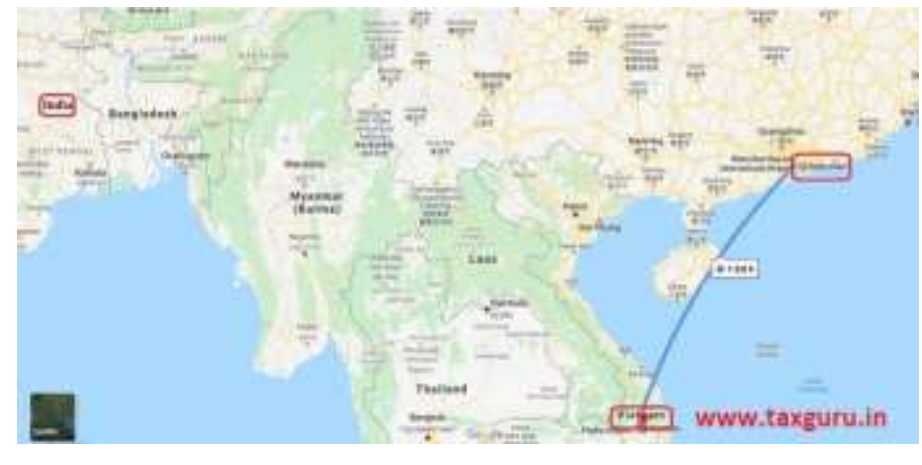

Image courtesy: taxguru

Another important factor in favour of Vietnam is that it has a large manufacturing hub which offers synergy to companies proposed to come to Vietnam unlike India where plants of companies are in different parts of the country to support overall development of the country.

\section{Technological Factors}

PESTLE refers to Level of technology, automation and incentives for inventing new products under technological factors. Though India is one of the fastest growing technological hubs, is lagging behind Vietnam in terms of Innovation. A research conducted in the year 2020 states that Vietnam (Ranked 42) is advanced than India (Ranked 48) in terms of Innovation. (GIIWIPO, 2020).

However, the Innovation potential needs to be backed up by appropriate infrastructure where in India score better as compared to Vietnam. The infrastructure sector has become the biggest focus area for the Government of India. India plans to spend US\$ 1.4 trillion on infrastructure during 2019-23 to have a sustainable development of the country (IBEF 2020). Realising the importance of the supporting infrastructure Vietnam has put in place measures to rectify infrastructural deficiencies and it is fast catching up with the requirements (Nahn Dan 2018). 
Despite above Vietnam has fared better than India in supply chain shifts. This is an important point which India needs to seriously ponder upon.

\section{Legal Factors:}

Prevalent laws like employment law, Labour welfare and health, Corporate Laws \& Level of corruption in the country etc. come under this category. . For starting a business in India (Source WBG Report 2020India), 10 procedures are required to be followed which will take 18 days on an average, whereas only 8 procedures (average 16 days' time) are required to be followed in Vietnam which makes it easy to start a business there (WBG ReportVietnam,2020) . Employment Laws \& Labour Unions in India are also not as strict in India owing to high rate of corruption and other reasons.

\section{Environmental Factors:}

PESTLE mainly refers to factors like environmental laws, Governmental Environmental Policies, Climate change and Average Temperatures etc. under environmental factors. Climatic factors are very important for IT and Electronics manufacturing companies as cost of cooling will be more in countries like India and Vietnam. These kinds of companies may move to European countries where the temperatures are expected to be comparatively low.

As per Environmental Performance Index Ranking in 2018, which ranks various nations based on Environmental Health and Ecosystem Vitality, Both India \& Vietnam have not been taking suitable steps towards maintaining sustainable environment. India and Vietnam ranked 177 and 132 among 180 countries (Wendling, et al, 2018).

\section{Summary}

It is evident from the above that India overall lacks in various vital parameters (as compared to Vietnam) which make a country a favoured destination for conducting business. But certainly all is not lost. The parameters are within the control of India to improve upon and prove it-self equally attractive destination when compared to Vietnam. India, therefore, needs to take cognisance of "for and against factors" and initiate actions to strengthen those in favour and set right those which are against (except geographical factors, which need to be compensated with other tangible incentives). The above analysis finds support in the study report of Kalyan (Kalyanpawan, 2020) also.

\section{Section H-Implications for India (Other than PESTLE Analysis)}

There are some other factors, other than those accounted for by the PESTLE, which affect decisions related to shift of supply chain. Apparently Vietnam has an edge over India in relation to such factors too. Some of the major factors have been enumerated in the succeeding paragraphs.

\section{Similarity in exports:}

A company considering shift of supply chain to another country, would need to consider availability of resources, facilities and similarity between both the countries to ensure similar 
business environment. Fig: 6 shows various countries with their similarity in exports as compared to China (Kalyanpawan, 2020a):

Fig: 6 Export Similar to China

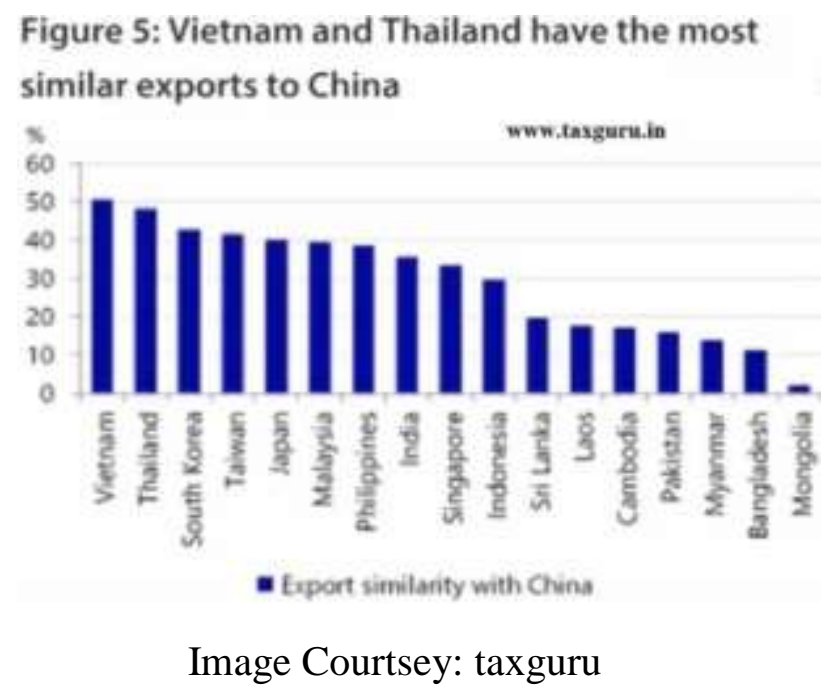

It would be seen that Vietnam \& Thailand are have similar exports with China.

\section{Free Trade Agreement \& Status given by other countries:}

Vietnam has concluded Free Trade Agreements (FTAs) with South East Asian countries like China, Japan etc. which reduces the trade barriers and encourages international trade. Vietnam is signatory to Regional Comprehensive Economic Partnership (RCEP). United States also gave Most Favoured Nation Status to Vietnam which makes easy for Vietnam to sell its products in US without any restriction.

In additions Vietnam is a member of Association of Southeast Asian Nations (ASEAN) which promotes intergovernmental cooperation and facilitates economic, political, security, military, educational, and sociocultural integration among its members and other countries in Asia. A total 12 FTAs have been concluded by Vietnam (Deshmukh, 2020).

In comparison India currently has 14 Regional Trade Agreements in place. However India has not member of crucial TPP \{Trance Pacific Partnership\} or RCEP \{Regional Comprehensive Economic Partnership\} (NITI Aayog, nd)

\section{Relationship with China:}

At the outset, others may find it as a negative aspect to have good relations with China. However Vietnam seems to have appreciated its own dependencies and advantages of maintaining good relations with China (Kalyanpawan, 2020b). Some of the important aspects are:-

a) Vietnam's proximity with China for ease of shift of supply chain

b) Cheaper Raw material supplies 
c) Feasibility of China overcoming trade restrictions imposed by India / United States / European Union by exporting via Vietnam thus establishing inter-dependency.

\section{Ease of Doing Business Ranking:}

Ease of doing Business is one of the most important factors for choosing a country for establishing a new business or shifting the established supply chain. India had a global ranking of 77 against Vietnam's 69, which makes that crucial difference (World Bank Report 2019a). A statistical Table related to India's and Vietnam's global ranking on ease of doing business, along with other parameters, has been placed at annexure for further reference (Kalyanpawan, 2020c).

\section{Other Aspects}

India has a good potential to improve its business potential by offering effective Electronics Manufacturing Services (EMS). ElectronicsB2B Report (ElectronicsB2B, 2019a) has rightly pointed out that:

According to a Research and Markets study, the Indian EMS market is expected to grow at a CAGR of 38.1 per cent till FY23, from an approximate Rs 560 billion in 2018. India can emerge as a hotspot for electronics manufacturing among the South Asian nations due to low operating costs. This provides ample opportunities for OEMs and EMS providers across different verticals.

It has also been observed that though Vietnam is currently a more desired option as an alternative for China, because of its labour quality, quantity, and higher work efficiency. However, in the short term, its industrial capacity would still fall short of the requirements, where India could step-in (Kalyanpawan, 2020d)

It's not a very happy situation that despite having a good potential, India has not been able to make itself attractive for foreign companies for investment, establishing manufacturing facilities or choose India as their valued supply chain partner. Lack of long term perspective/quick decision making capabilities/will to make right investment at right time/political and economic stability/discipline and transparency, all have deterred foreign companies from coming to India.

\section{Suggested actions for India}

To compete with Vietnam India needs to take cognisance of the abovementioned factors and initiate remedial measures on fast track, to stay relevant in the game. It's really a "now or never" situation for India and government needs to give a strong push for setting right the impediments.

Chakrabarty (Chakrabarty 2019) has rightly stated that India needs to put greater emphasis on developing closer economic ties with the Association of South-East Asian Nations (ASEAN) because the region is a major hub of manufacturing activities and its share in global output, foreign direct investments, exports, and imports have grown consistently. 
Within the ASEAN, Vietnam has become an export powerhouse and has often been dubbed as a miracle economy. Though India has undertaken several initiatives in recent years to boost its economic ties with Vietnam, under the Mekong-Ganga Cooperation and its engagement with the CLMV (Cambodia, Laos, Myanmar, and Vietnam) sub-region, but the efforts have not proven adequate to yield tangible results.

Vietnam has been looking for developing closer ties in the textiles and garments industry in India. Such efforts have not met with much success. This is largely because the Indian textile and garments industry has been in bad shape and it's not globally competitive. India's product quality also has not been at par with other countries and Indian firms have typically failed to meet the tight schedule of the value chain.

In addition, India's development cooperation strategy in Vietnam has also not been very helpful in promoting India's economic engagements in that country and a strong push from the Indian government would be urgently needed.

Chakrabarty (ibid) has further pointed out that "With an underperforming manufacturing sector, sluggish export growth, and job losses in the manufacturing in the last couple of months, business as usual cannot be an option for India'. To achieve the target of increasing manufacturing share in GDP to $25 \%$, India needs to learn from the experience of other countries in Asia like Vietnam, which have industrialised very rapidly in a short span of time.

They also got integrated into regional value chains because over three-quarters of global trade takes place through value chains. In a nutshell, stronger strategic partnership with Vietnam is a must and India needs to strive to build that.

A reputed analyst- Neeraj Bansal (Bansal2020a) has said on the subject that:

While India has many of the ingredients to emerge as the preferred market for global investments and manufacturing, it is critical that the government maintains both the pace as well as scalability of reforms, while strengthening infrastructure growth.

Regulatory and investment reforms will need to integrate progressive policy changes in land, incentives and infrastructure, with foreign investment norms and tax regimes. India also needs a more aggressive approach in reaching out to global companies to expand their business footprint in the country.

India also needs to realise that Vietnam is not perfect, it too has its own weaknesses in terms of:-

a) Domestic market demand and the overseas demand. While in India, domestic demand alone will be suffice

b) Confined and weak Industrial and manufacturing developments

c) Lack of Raw material resources. 
Another study has opined that various companies contemplating this type of shift, especially to Vietnam, may need to keep in mind factors like (Flexport, 2019):-

- Nascent (but growing) transport infrastructure compared to China

- The rapidly changing trade restriction policy environment

- The time it takes to fully shift supply chains

It's important for India to be cognisant of the problems of Vietnam. To reiterate, India should help Vietnam in overcoming the problems, by partnering with it in a synergetic manner. This would help India not only in creating a win-win situation for both the countries but also creating an ally against China in the bargain.

\section{Analytical Summary}

The World Bank (WB overview-Vietnam, 2020) for Vietnam brings out that:

Owing to its strong fundamentals, and assuming the relative control of the COVID-19 pandemic both in Vietnam and the world, the Vietnamese economy should rebound in 2021. COVID-19 has also shown the necessity for stronger reforms to help the economy recover in the medium term, such as improving business environment, promoting the digital economy, and enhancing public investment effectiveness and efficiency, which are some of the key agendas for Vietnam to consider stronger and faster reform actions.

Similarly the World Bank (WB Overview-India, 2020) for India brings out that "In the fiscal year starting in April 2020, India's economy is expected to contract by 9.6 percent, and recover only very gradually thereafter, with risks tilted on the downside. Weak activity, domestically and abroad, is also likely to depress both Indian imports and exports".

The significant fiscal and other policy responses announced by both the federal and state governments are expected to provide some relief, mostly to avoid an even deeper contraction. But, a potential source of risk to this effort stems from pre-existing financial sector weaknesses and high levels of NPAs, which have been amplified by the crisis.

But World Bank's predictions are at best predictions and Author opines that India has resilience enough to break out of the shell and establish itself on the path of positive economic recovery.

From further analysis of the World Bank reports it is opined that:-

a) It may be unlikely that India or Vietnam would qualify to be called the new China in short to medium term.

b) But India will most probably rise up as another giant (though no match to China) certainly bettering its economic and geopolitical might and improving quality of life for its citizens.

c) Vietnam is more likely to be the next South Korea, and be an important support to Chinese manufacturing industry, as the supplement to the global supply chain. 
That said, world would be watching to see who will rise up as the new China in the long run. Author would like to put his lot with India. It would be pertinent to quote a statement by acclaimed analyst on the subject (Taneja, 2020):

With India's strong macro-economic fundamentals, favourable demographic dividend, improved ease of doing business (EoDB), and availability of resources for ramping up manufacturing capacities, the country can position itself as an attractive investment destination for investors across the globe. This would require the government, local bodies and the industry to leverage this opportunity optimally. This would also give India a chance for - Building a better working world!

\section{Section I - Conclusion and Recommendations}

Sanskrut Subhashita (slideshare, nd) “श्रूयतां धर्मसर्वस्वं श्रुत्वा चैवावधार्यताम्|आत्मनः प्रतिकूलानि परेषां न समाचरेत्॥ Shrutyaam Dharmasarvasvam shrutwa chaivavdhaaryataam Aatman pratikulaani pareshaam na samaacharet" meaning.... "Listen to the gist of the code of life, and never forget it. Never impose anything on others that you won't like to go through", well illustrates China's condition today. In that China seems to be facing some effects of its arrogance, self-serving attitude and territorial ambitions, on various fronts, including trade related issues.

Multiple reasons like rising labour costs, hegemonic attitude, trade war with US and mishandling of Covid-19 crisis have jeopardised future of the supply chains in China. Many global companies have already started shifting of their supply chains out of China.

India and Vietnam were predicted to be the most favoured countries for the shift. But factually Vietnam has stolen a big march over India for various reasons, including bureaucratic tangles/ inadequate infrastructure. India needs to urgently address these issues.

It is recommended that to improve upon its prospects, India should:-

a) Create conducive atmosphere for business by setting right political wrangles and internal strife, as they act as dampeners for foreign investment.

b) Bring in tough laws against arson and damage to business infrastructure by rioters

c) Bring in discipline, transparency to make processes more efficient and reduce protectionism and bureaucratic jingoism.

d) Offer financial incentives, create last mile connectivity and, most importantly ensure availability of comparatively low-cost but quality labour.

e) Conclude free trade agreements with ASEAN/EU/BIMSTEC countries.

f) Improve its geopolitical and economic ties with ASEAN/BIMSTEC/QUAD counties. 
g) Deepen its economic engagements with Vietnam to form a strong politico-economic partnership.

h) Improve its social, logistical infrastructure and environmental index ( in terms of air/water quality)

Lastly, four -yet unclear- issues which may have an impact on the subject at hand and which need to be studied further are:-

a) For many years, the cost of 'distance' has determined where businesses produce and sell and where employers locate jobs. How would the global economy change if manufacturers could produce locally in small batches, without incurring excess cost? Would existing business models and supply chains, for instance, suddenly become uncompetitive, if people could work from anywhere?

b) Impact of change of guard in US on US-China relationship is still not very clear, as it's closely related to trade war between them. Any change in strategy by US would reconfigure the scenario, warranting further analysis.

c) Impact of China's tantrums and South China Sea dispute on strengthening IndiaVietnam Partnership.

d) The real Impact of The Regional Comprehensive Economic Partnership (RCEP) - a free trade agreement between the Asia-Pacific nations of Australia, Brunei, Cambodia, China, Indonesia, Japan, Laos, Malaysia, Myanmar, New Zealand, the Philippines, Singapore, South Korea, Thailand, and Vietnam (signed on 15 Nov 2020) on India, ASEAN, BIMSTEC and USA

\section{Acknowledgment}

Author would like to place on record his gratitude to Dr R Srinivasan for his valuable guidance and constant motivation and Ms Sujata Deshmukh for seeing him through some tumultuous times.

\section{References:}


1. Waller Allen Professor (ND), Supply Chain Quotes, Retrieved from: https://www.google.com/search?q=supply+chain+quotes\&rlz=1C1RXQR_enIN931IN931\&t bm=isch\&source=iu\&ictx=1\&fir=QXTDrRZPQinXvM\%252CivHfgy9wFYpuiM\%252C_\& vet $=1 \&$ usg $=$ AI4_kS7kfIsPVk1 ACtz3Ag4xEU3x0UI7g\&sa=X\&ved=2ahUKEwjEx6q1r47vAhXOQ30KHTUc DPkQ9QF6BAgEEAE\&biw=1366\&bih=657\#imgrc=suH1jP6ry7NzdM , accessed on $01 \mathrm{Mar}$ 2021

2. Ballou RH (2006), SciELO Analytics Prod. vol.16 no.3 São Paulo Sept./Dec. 2006,The evolution and future of logistics and supply chain management, Retrieved from: http://www.scielo.br/scielo.php?script=sci_arttext\&pid=S0103-65132006000300002 Accessed on 08 Nov 2020

3. Wong Dorcas and Koty Alexander Chipman (2020), China Briefing, The US-China Trade War: A Timeline, Retrieved from: https://www.china-briefing.com/news/the-uschina-trade-war-a-timeline/ Accessed on 22 and 23 Oct 2020

4. Kenton Will (2020), Investopedia, Supply Chain, Retrieved from: https://www.investopedia.com/terms/s/supplychain.asp, accessed on 01 Mar 2021

5. Bailey Mary Page (2020), Borderless, The New Era of Sustainable Supply Chains, Retrieved from: https://www.borderless.net/news/chemical-value-chain/the-new-era-ofsustainable-supply-chains/ accessed on 01 Mar 2021

6. Hackett Group (2013), Supply Chain247, “Borderless Business Environment” Driving New Pressure, Changing Priorities for Procurement Leaders, Retrieved from: https://www.supplychain247.com/article/borderless_business_environment_driving_new_pressure_changing _priorities/the_hackett_group, accessed on 01 Mar 2021

7. Ballou RH (2006a), SciELO Analytics Prod. vol.16 no.3 São Paulo Sept./Dec. 2006, The evolution and future of logistics and supply chain management, Retrieved from: http://www.scielo.br/scielo.php?script=sci_arttext\&pid=S010365132006000300002 Accessed on 08 Nov 2020

8. CSMCP Glossary (nd), /a, Definitions and Glossary of Terms, Retrieved from: https://cscmp.org/CSCMP/Educate/SCM_Definitions_and_Glossary_of_Terms.aspx\#: :text= Logistics\%20management \%20is\%20that\%20part,order\%20to\%20meet\%20customers'\%20re quirements. Accessed on 16 Jan 2021

9. Rapoza Kenneth (2020), Forbes, The Coming 'Breaking' Of The China Supply Chain , Retrieved from: https://www.forbes.com/sites/kenrapoza/2020/05/17/the-coming-breakingof-the-china-supply-chain/?sh=10659d5a5d04, accessed on 17 Jan 2021

10. Ceglowski, Janet, and Golub Stephen S (2012), Global Economy Journal 12, no. 3 (2012), Does China Still Have a Labour Cost Advantage? (DOI: 10.1515/1524-5861.1874), Retrieved from: accessed on 18 Oct 2020

11. Cyrill Melissa (2019), China Briefing, Retrieved from: https://www.chinabriefing.com/news/shifts-chinas-industrial-supply-chain-trade-war/ accessed on 18 Oct 2020 
12. Gupta Yogesh (2020/a), Tribune India, Shift of supply chains from China accelerates, Retrieved from: https://www.tribuneindia.com/news/comment/shift-of-supply-chains-fromchina- accelerates-81847, accessed on 18 Oct 2020

13. Wong Dorcas and Koty Alexander Chipman (2020a), China Briefing, The US-China Trade War: A Timeline, Retrieved from: https://www.china-briefing.com/news/the-uschina-trade-war-a-timeline/ Accessed on 22 and 23 Oct 2020

14. Consultancy Asia (2020), Why moving supply chains from China to ASEAN isn't that easy Retrieved from: https://www.consultancy.asia/news/3595/why-moving-supply-chainsfrom-china-to-asean-isnt-that-easy accessed on 18 and 19 Oct 2020

15. Pamuk H and Shahal A (2020), Reuters, Trump administration pushing to rip global supply chains from China, Retrieved from: https://www.reuters.com/article/us-healthcoronavirus-usa-china/trump-administration-pushing-to-rip-global-supply-chains-from-chinaofficials-idUSKBN22G0BZ, accessed on 17 Jan 2021

15. Singh Aditya (2020), Self-Published, Retrieved from: https://www.linkedin.com/pulse/vietnam-wins-asia-mexico-south-america-adityasingh/?articleId=6671979080541315072 accessed om 17, 18 and 23 Oct 2020.

16. Reynolds I and Urabe E (2020/a), Bloomberg, Japan to Fund Firms to Shift Production Out of China, Retrieved from: https://www.bloomberg.com/news/articles/2020-04-08/japan-to-fundfirms-to-shift-production-out-of-china Accessed on 08 Nov 2020

17. Staff Reporter (2020), ET Auto.com, Japan to fund firms to shift production out of China, Retrieved from: https://auto.economictimes.indiatimes.com/news/industry/japan-tofund-firms-to-shift-production-out-of-china/75053048, accessed on 14 Jan 2021

18. Consultancy Asia, $30(2020 \mathrm{a} / \mathrm{b} / \mathrm{c})$, Why moving supply chains from China to ASEAN isn't that easy Retrieved from: https://www.consultancy.asia/news/3595/why-moving-supplychains-from-china-to-asean-isnt-that-easy accessed on 18 and 19 Oct 2020

19. Reynolds I and Urabe E (2020b), Bloomberg, Japan to Fund Firms to Shift Production Out of China, Retrieved from: https://www.bloomberg.com/news/articles/2020-04-08/japan-to-fundfirms-to-shift-production-out-of-china Accessed on 08 Nov 2020

20. Consultancy Asia (2020d), Why moving supply chains from China to ASEAN isn't that easy Retrieved from: https://www.consultancy.asia/news/3595/why-moving-supplychains-from-china-to-asean-isnt-that-easy accessed on 18 and 19 Oct 2020

21. Khan Arbaz (2020), The Indian Wire, Global backlash towards China over coronavirus outbreak , Retrieved from https://www.theindianwire.com/business/companies-pack-upproduction-in-china-loses-33-of-foreign-production-market-283310/ accessed on 18 Oct 2020 
22. Reynolds I and Urabe E (2020c), Bloomberg, Japan to Fund Firms to Shift Production Out of China, Retrieved from: https://www.bloomberg.com/news/articles/2020-04-08/japan-to-fundfirms-to-shift-production-out-of-china Accessed on 08 Nov 2020

23. Gartner survey (2020), DC Velocity, 33\% of companies are moving their supply chains out of China, Retrieved from: https://www.dcvelocity.com/articles/46383-gartner-survey-33of-companies-are-moving-their-supply-chains-out-of-china, accessed on 16 Jan 2021

24. Singh Aditya (2020a), Self-Published, Retrieved from: https://www.linkedin.com/pulse/vietnam-wins-asia-mexico-south-america-adityasingh/?articleId=6671979080541315072 accessed on 17, 18 and 23 Oct 2020.

25. Mah Kyssha (2020), Vietnam Briefing, Supply Chain shifts from China to Vietnam, Retrieved from: https://www.vietnam-briefing.com/news/supply-chain-shifts-chinavietnam.html/ accessed on 18 and 19 Oct 2020.

26. Blackham S (2020/a), supplychainbrain.com, Why U.S. Companies Are Moving Their Supply Chains From China to Mexico, Retrieved from: https://www.supplychainbrain.com/blogs/1-think-tank/post/31037-why-us-companies-aremoving-their-supply-chains-from-china-to-mexico__Accessed on 17 Jan 2021

27. Roy A (2020), Business Standard, Relocation of supply chains from China to benefit India the most, Retrieved from: https://www.business-standard.com/article/economypolicy/relocation-of-supply-chains-from-china-to-benefit-india-the-most-nomura120071601266_1.html, accessed on 16 Jan 2021

28. Singh Aditya (2020b), Self-Published, Retrieved from: https://www.linkedin.com/pulse/vietnam-wins-asia-mexico-south-america-adityasingh/?articleId=6671979080541315072 accessed om 17, 18 and 23 Oct 2020.

29. Coates R, (Q1/2021), Area Development, Challenges of Moving Manufacturing Out of China, Retrieved from: https://www.areadevelopment.com/BusinessGlobalization/Q12021/challenges-of-moving-manufacturing-out-of-china.shtml, accessed on 16 Jan 2021

30. Xavier Francis (2020), Eurasian Times, After China \& Pakistan, India \& Vietnam Emerging As The Next "Iron Brothers" Of Asia, Retrieved from: https://eurasiantimes.com/after-china-pakistan-india-vietnam-emerging-as-the-next-ironbrothers-of-asia-experts/ accessed on 17, 18 and 23 Oct 2020

31. Mazumdar Rahul ( 2020), The Hindu, Forget China, can India match Vietnam? | Retrieved from: https://www.thehindubusinessline.com/opinion/forget-china-can-india-matchvietnam/articles32506729.ece, accessed on 18 Oct 2020

32. Sharma R (Quoted in Eurasian Times), 06 Oct 2020, Eurasian Times Desk. Vietnam Beats China, India to Become Next Manufacturing Hub (Reports) Retrieved from:

https://eurasiantimes.com/vietnam-beats-china-india-to-become-next-manufacturing-hubreports/_Accessed on 16 Jan 2021

33. Staff Reporter (2020), Eurasian Times (Eurasian Times Desk), Vietnam Beats China, India to Become Next Manufacturing Hub (Reports) Retrieved from: 
https://eurasiantimes.com/vietnam-beats-china-india-to-become-next-manufacturing-hubreports/, accessed on 16 Jan 2021

34. Mazumdar Rahul (2020a/b) , The Hindu, Forget China, can India match Vietnam? | Retrieved from: https://www.thehindubusinessline.com/opinion/forget-china-can-india-matchvietnam/articles32506729.ece, accessed on 18 Oct 2020

35. Bansal N, 06 Oct 2020, KPMG, Supply Chain Re-alignment, Retrieved from: https:/home.kpmg/in/en/home/insights/2020/10/global-supply-chain-reconfiguration.html, accessed on 16 Jan 2021

36. Mah Kyssha (2020b), Vietnam Briefing, Supply Chain shifts from China to Vietnam, Retrieved from: https://www.vietnam-briefing.com/news/supply-chain-shifts-chinavietnam.html/ accessed on 18 and 19 Oct 2020.

37. Kumar Vipul (2020), ET Auto Times- India Times, and (ET Auto Original): Who Will Replace China- India or Vietnam? Retrieved from: https://auto.economictimes.indiatimes.com/news/industry/opinion-who-will-replace-chinaindia-or-vietnam/75864530 accessed on 19 Oct 2020

38. Mazumdar Rahul (2020c), The Hindu, Forget China, can India match Vietnam? | Retrieved from: https://www.thehindubusinessline.com/opinion/forget-china-can-india-matchvietnam/articles32506729.ece, accessed on 18 Oct 2020

39. Mah Kyssha (2020c), Vietnam Briefing, Supply Chain shifts from China to Vietnam, Retrieved from: https://www.vietnam-briefing.com/news/supply-chain-shifts-chinavietnam.html/ accessed on 18 and 19 Oct 2020.

40. Dutta PK (2020), India Today, Covid Spill-over: Firms shifting from China to Vietnam has a lesson for India, Retrieved from: https://www.indiatoday.in/business/story/covid-spillover-firms-shifting-fromchina-to-vietnam-has-lesson-for-india-1687344-2020-06-10, Accessed on 10-11 Oct 2020.

41. Staff Reporter (2020a), Eurasian Times (Eurasian Times Desk), Vietnam Beats China, India to Become Next Manufacturing Hub (Reports) Retrieved from:

https://eurasiantimes.com/vietnam-beats-china-india-to-become-next-manufacturing-hubreports/ Accessed on 16 Jan 2021

42. Kumar Vipul (2020a/b), ET Auto Times- India Times, (ET Auto Original): Who Will Replace China- India or Vietnam? Retrieved from: https://auto.economictimes.indiatimes.com/news/industry/opinion-who-will-replace-chinaindia-or-vietnam/75864530 accessed on 19 Oct 2020

43. Global Economy Rankings Report (2019), globlaeconomy.com, Seaport Quality -Port Infrastructure Quality, Retrieved from: https://www.theglobaleconomy.com/rankings/seaports_quality/Port infrastructure quality Country rankings, Accessed on 20 Mar 2021.

44. The Economist Ranking Report (2018), The Economist (with ABB), WHO IS READY FOR THE COMING WAVE OF AUTOMATION? Retrieved from: 
https://www.automationreadiness.eiu.com/\#overview, accessed on 28 Oct 2020 and 14 Jan 2021.

45. Vu Khuang and Asher Mukul G (2009), Research Gate, India-Vietnam: A Comparative Analysis of Economic Performance, Retrieved From:

https://www.researchgate.net/publication/262066359_India-

Vietnam_A_Comparative_Analysis_of_Economic_Performance, Accessed on 09-10 Nov 2020

46. PESTLE Analysis (ND), PESTLE Analysis Concepts, Retrieved from: https://pestleanalysis.com/category/pest-analysis/ Accessed on 12 Nov 2020

47. Professional Academy Blog (ND), PESTLE Analysis Concepts, Retrieved from: https://www.professionalacademy.com/blogs-and-advice/marketing-theories---pestelanalysis\#: :text=A\%20PESTEL\%20analysis\%20or\%20more,used\%20in\%20a\%20SWOT\%2 Oanalysis. Accessed on 12 Nov 2020

48. Global Economy Index Report (2019), Global Economy.com, Political Stability Country Rankings, Retrieved from: https://www.theglobaleconomy.com/rankings/wb_political_stability/ accessed on 03 Mar 2021

49. GII-WIPO Report -Global Innovation Index-GII (2019), Cornell University, country wise Global Innovation Index, Retrieved from: https://www.wipo.int/edocs/pubdocs/en/wipo_pub_gii_2019/vn.pdf, Accessed on 20 Mar 2021

50. Reuters (2019), India Today, India's Financial System Stable Despite Wreaking Economic Growth, Retrieved from: https://www.indiatoday.in/business/story/india-sfinancial-system-stable-despite-weakening-economic-growth-says-rbi-1632106-2019-12-28, accessed on 19 mar 2021

51. RBI Report -FSR19 (2019) , Retrieved from: https://rbidocs.rbi.org.in/rdocs/PublicationReport/Pdfs/FSRJUNE2019E5ECDDAD7E51475 6AFEF1E71CB2ADA2B.PDF, accessed on 19-20 Mar 2021

52. World bank Report (2019), Retrieved from: https://www.worldbank.org/en/news/press-release/2019/12/17/vietnams-economy-expandedby-68-percent-in-2019-but-reforms-are-needed-to-unleash-the-potential-of-

capitalmarkets\#: :text=Hanoi\%2C\%20December\%2017\%2C\%202019\%E2\%80\%94,of\%20a $\% 20$ slowing\%20global\%20economy. Accessed on 19-29 Mar 2021

53. WB2019 Report -Web Version pdf (2019), OECD.Stat, oecd fdi regulatory restrictiveness index, Retrieved from: http://mddb.apec.org/Documents/2019/CTI/WKSP4/19_cti_wksp4_007.pdf

54. Shariff A (2020), The Hindu, A sad scenario in India (Shariff, 2020). Social diversity \& economic growth, Retrieved from: https://frontline.thehindu.com/coverstory/article30433461.ece, accessed on 19 Mar 2021 
55. Doing Business 2019 ( Training For Reform)-A World Bank Group Flagship Report (2019),

Retrieved

From: https://www.doingbusiness.org/content/dam/doingBusiness/media/AnnualReports/English/DB2019-report_web-version.pdf accessed on 03 Mar 2021

56. The ComConnect-Consulting Research Team (2019), Electrinicsb3b.com. India must emerge as a global EMS hub, retrieved from: https://www.electronicsb2b.com/ebspecials/leading-electronics-manufacturing-service-providers-of-india/india-must-emerge-asa-global-ems-hub/, accessed on 03 Mar 2021.

57. Government Statistics Office ( GSO) Vietnam (2019), SOCIO-ECONOMIC SITUATION IN THE THIRD QUARTER AND NINE MONTHS OF 2019, Retrieved from: https://www.gso.gov.vn/en/data-and-statistics/2019/10/report-social-and-economic-situationin-the-3rd-quarter-and-the-9-months-of-2019/,

Accessed on-20 Mar 2021.

58. World Bank Survey report (WB- 2020) , Retrieved from: https://data.worldbank.org/indicator/SL.TLF.CACT.FM.ZS, accessed on 12 Nov 2020

59. WIPO Global Innovation Index (2020a), Retrieved from: https://www.wipo.int/edocs/pubdocs/en/wipo_pub_gii_2020-intro4.pdf

Accessed on 17 Jan 2021

60. India Brand Equity Foundation-IBEF (2020), Infrastructure Sector in India, retrieved From: https://www.ibef.org/industry/infrastructure-sector-india.aspx

Accessed on 12 Nov 2020

61. Excerpts from: Vietnamese PM Interview (2018), Nahn Dan , Retrieved from: https://en.nhandan.com.vn/business/economy/item/5882402-poor-infrastructure-slowsvietnam\%E2\%80\%99s-development-pm.html

Accessed on 12 Nov 2020

62. World Bank Survey report-India (WB 2020a) , Retrieved from: https://data.worldbank.org/indicator/SL.TLF.CACT.FM.ZS, accessed on 12 Nov 2020

63. World Bank Group Report-India ( WBG 2020), Doing Business India, Retrieved from: https://www.doingbusiness.org/content/dam/doingBusiness/country/i/india/IND.pdf Accessed on 12 Nov 2020

64. World Bank Group Report-Vietnam (WBG 2020), Doing Business Vietnam, Retrieved From:

https://www.doingbusiness.org/content/dam/doingBusiness/country/v/vietnam/VNM.pdf Accessed on 12 Nov 2020.

65. Wendling, Z. A., Emerson, J. W., Esty, D. C., Levy, M. A., de Sherbinin, A., et al. (2018), Environmental Performance Index. New Haven, CT: Yale Center for Environmental Law \& Policy. Retrieved from: https://epi.yale.edu/

Accessed on 12 Nov 2020 
66. Kalyanpawan (2020/a), taxguru, Why Companies exiting China are choosing Vietnam over India?, Retrieved from:

https://taxguru.in/finance/companies-exiting-china-choosing-vietnam-india.html Accessed on 20 Oct 2020

67. Deshmukh Atharva (2020), globalriskinsights, EU - Vietnam Free Trade Agreement: Vietnam's Competitive Gains, Retrieved from: ,https://globalriskinsights.com/2020/05/euvietnam-free-trade-agreement-vietnams-

competitivegains/\#: :text=It\%20is\%20one\%20among\%20many,Japan\%2C\%20Canada\%20 and\%20South\%20Korea. Accessed on 20 Mar 2021.

68. NITI Aayog Report on FTAs-India (ND), Retrieved from : ndwww.niti.gov.in, accessed on 20 Mar 2021

69. Kalyanpawan (2020b), taxguru, Why Companies exiting China are choosing Vietnam over India?, Retrieved from:

https://taxguru.in/finance/companies-exiting-china-choosing-vietnam-india.html Accessed on 20 Oct 2020

70. Doing Business 2019 ( Training For Reform)-A World Bank Group Flagship Report (2019),

Retrieved

From:

https://www.doingbusiness.org/content/dam/doingBusiness/media/Annual-

Reports/English/DB2019-report_web-version.pdf accessed on 03 Mar 2021

71. The ComConnect Consulting Research Team (2019a), Electrinicsb3b.com, India must emerge as a global EMS hub, Retrieved from: https://www.electronicsb2b.com/ebspecials/leading-electronics-manufacturing-service-providers-of-india/india-must-emerge-asa-global-ems-hub/, accessed on 03 Mar 2021.

72. Kalyanpawan (2020c), taxguru, Why Companies exiting China are choosing Vietnam over India?, Retrieved from:

https://taxguru.in/finance/companies-exiting-china-choosing-vietnam-india.html Accessed on 20 Oct 2020

73. Chakrabarty Malancha (2020), Economic Times India (in ET Commentary), India needs to gear up for stronger economic partnership with old ally Vietnam, Retrieved from: https://economictimes.indiatimes.com/blogs/et-commentary/india-needs-to-gear-up-forstronger-economic-partnership-with-old-ally-vietnam/_ accessed on 20 Oct 2020

74. Bansal N (2020a), KPMG, Supply Chain Re-alignment, Retrieved from: https:/home.kpmg/in/en/home/insights/2020/10/global-supply-chain-reconfiguration.html, accessed on 16 Jan 2021

75. Flexport (2020), Flexport.com, New Hurdles Arise As Manufacturing Looks to Vietnam During US-China Trade War, Retrieved From:

https://www.flexport.com/blog/china-to-vietnam-manufacturing-shift/

Accessed on 22 and 23 Oct 2020

76. The World bank Report (2020). World Bank, Vietnam Overview, Retrieved from: https://www.worldbank.org/en/country/vietnam/overview, Retrieved on 23 Oct 2020 
77. The World bank Report (2020), World Bank, India Overview, Retrieved from: https://www.worldbank.org/en/country/india/overview, Retrieved on 23 Oct 2020,

78. Taneja G (2020), EY, Retrieved from: https://www.ey.com/en_in/government-publicsector/can-india-seize-the-opportunity-in-the-global-supply-chain-arena-post-covid-19, accessed on 16 Jan 2020.

79. Sanskrit

Subhashita:

retrieved from https://www.slideshare.net/arathiGunduRao/shubhashitaassanskrit-proverbs-for-dailyessence-of-life, accessed on 08 Nov 2020

80. Kalyanpawan (2020d), taxguru, Why Companies exiting China are choosing Vietnam over India?, Retrieved from:

https://taxguru.in/finance/companies-exiting-china-choosing-vietnam-india.html Accessed on 20 Oct 2020

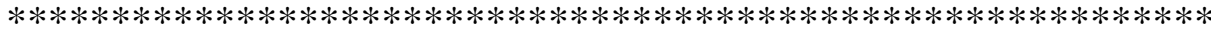

\section{Annexure:}

Table related to the important factors determining 'Ease of Doing Business' Table (Kalyanpawan, 2020d)

\begin{tabular}{|l|l|l|}
\hline Parameter & India & Vietnam \\
\hline Ease of Doing Business & 77 & 69 \\
\hline Starting a Business & 137 & 104 \\
\hline Dealing with Construction Permits & 52 & 21 \\
\hline Getting Electricity & 24 & 27 \\
\hline Registering Property & 166 & 60 \\
\hline Getting Credit & 22 & 32 \\
\hline Protecting Minority Investors & 07 & 89 \\
\hline Paying Taxes & 121 & 131 \\
\hline Trading across Borders & 80 & 100 \\
\hline Enforcing Contracts & 163 & 62 \\
\hline Resolving Insolvency & 108 & 133 \\
\hline
\end{tabular}


It is evident from the above that Vietnam is much better placed as compared to India in many aspects. India surely needs to catch up, the time is now to act based in its analysis of strength and weaknesses of Vietnam (which were reflected upon in the paper).

Source: Kalyanpawan, 17 Jul 2020d, taxguru, Why Companies exiting China are choosing Vietnam over India?, Retrieved from:

https://taxguru.in/finance/companies-exiting-china-choosing-vietnam-india.html Accessed on 20 Oct 2020

$* * * * * * * * * * * * * * * * * * * * * * * * * * * * * * * * * * * * * * * * * * * * * * * * * * * * * * * * * * * * * * * * * * * * * * * * * * * *$ 